\title{
Alteration in localization of steroid hormone receptors and coregulatory proteins in follicles from cows with induced ovarian follicular cysts
}

\author{
Natalia R Salvetti ${ }^{1,2}$, Natalia S Alfaro ${ }^{1}$, Melisa M L Velázquez ${ }^{1,2}$, Ayelen N Amweg ${ }^{1,2}$, \\ Valentina Matiller ${ }^{1}$, Pablo $\cup$ Díaz ${ }^{1,2}$ and Hugo $\mathrm{H}_{\text {Ortega }}{ }^{1,2}$ \\ ${ }^{1}$ Morphological Sciences Department, Faculty of Veterinary Sciences, National University of Litoral (FCV-UNL), \\ R.P. Kreder 2805, 3080 Esperanza, Santa Fe, Argentina and ${ }^{2}$ Argentine National Research Council (CONICET), \\ Buenos Aires, Argentina
}

Correspondence should be addressed to H H Ortega at Morphological Sciences Department, Faculty of Veterinary Sciences, National University of Litoral (FCV-UNL); Email: hhortega@fCv.unl.edu.ar

N R Salvetti and N S Alfaro contributed equally to this work

\begin{abstract}
Cystic ovarian disease (COD) is an important cause of infertility in cattle. The altered follicular dynamics and cellular differentiation observed in COD may be mediated through a disruption of the expression of steroid receptors and their associated transcriptional cofactors. The aim of this study was to determine the protein expression profiles of ESR1, ESR2, PGR, AR, NCOA3, NCOR2, and PHB2 (REA) in ovarian follicles in an experimental model of COD induced by the administration of ACTH. Ovaries were collected and follicles were dissected from heifers during the follicular phase (control) or from heifers treated with ACTH to induce the formation of ovarian follicular cysts. Ovaries were fixed, sectioned, and stained immunohistochemically for steroid receptors and the associated transcription factors. The relative expression of ESR1 was similar in follicular cysts and in tertiary follicles from both control and cystic cows and was significantly higher than in secondary follicles. The expression of ESR2 in the granulosa was higher in cystic follicles. No differences were seen for PGR. The expression of androgen receptor was significantly increased in tertiary follicles with lower immunostaining in cysts. The expression of NCOA3 was observed in the granulosa and theca with a significantly increased expression in the theca interna of cystic follicles. The highest levels of NCOR2 expression in granulosa, theca interna, and theca externa were observed in cysts. In granulosa cells, NCOR2 levels increase progressively as follicles mature and the treatment had no effect. In summary, ovaries from animals with induced COD exhibited altered steroid receptor expression compared with normal animals, as well as changes in the expression of their regulators. It is reasonable to suggest that in conditions characterized by altered ovulation and follicular persistence, such as COD, changes in the intra-ovarian expression of these proteins could play a role in their pathogenesis.

Reproduction (2012) $\mathbf{1 4 4}$ 723-735
\end{abstract}

\section{Introduction}

Cystic ovarian disease (COD) is an important cause of infertility and has been reported in many species, including cows, sheep, and pigs. Many factors, such as stress, nutritional management, and infectious disease, can lead to COD. The primary cause of this disease has not yet been elucidated, although an intra-ovarian component is involved in its pathogenesis (Silvia et al. 2002, Peter 2004, Vanholder et al. 2006). In this context, ovarian folliculogenesis is a complex process of morphological and biochemical events regulating the growth and differentiation of follicles from the primordial to the preovulatory stage and ovulation. In this process, steroids play a key role in the growth, differentiation, and function of ovarian follicles. Locally produced androgens, estrogens, and progesterone are involved in the regulation of different follicular functions (Rosenfeld et al. 2001, Drummond et al. 2002, Schams \& Berisha 2002, Brosens 2004, Drummond 2006, Kimura et al. 2007, Ortega et al. 2009).

The locations of steroid hormone receptors within ovarian follicles have been evaluated using a variety of techniques (Manikkam et al. 2001, Cassar et al. 2002, Jo et al. 2002, Schams \& Berisha 2002, Van den Broeck et al. 2002a, 2002b, Hampton et al. 2004, D'Haeseleer et al. 2005). It has been demonstrated that either estrogen or estrogen receptor (ESR) imbalances/disturbances may result in the development of ovarian follicular cysts in cattle (Garverick 1997, Salvetti et al. 2007, 
Alfaro et al. 2012), sheep (Ortega et al. 2009), humans (Shushan et al. 1996, Jakimiuk et al. 2002), and rodents (Salvetti et al. 2009a). However, one problem with previous studies is that follicular tissues were collected from abattoirs where the reproductive history of the animals was not known.

On the other hand, recent studies have demonstrated that the transcriptional activity of steroid hormone receptors is determined not only by hormone binding but also by the relative activities of nuclear receptorassociated coactivators and corepressors (Mussi et al. 2006). The equilibrium between coregulators and the nature of the ligand combines to determine the state of nuclear receptor activation or inhibition (Park et al. 2005). Some of the most important coactivators are the nuclear receptor coactivators (NCOAs), also referred to as steroid receptor coactivators (SRCs). These include NCOA1 (SRC1), NCOA2 (SRC2/GRIP1/TIF2), and NCOA3 (SRC3/pCIP/ACTR/AIB1/RAC-3/TRAM-1) (McKenna et al. 1999). On the other hand, one of the most widely studied corepressors, nuclear receptor corepressor 2 (NCOR2) or silencing mediator of retinoid and thyroid receptors (SMRT), was first discovered and identified through its interaction with thyroid and retinoid hormone receptors (Chen \& Evans 1995, Hörlein et al. 1995). Another important molecule is the repressor of ESR activity (PHB2 (REA)), which interacts with selected steroid receptors, such as ESR (Montano et al. 1999, Delage-Mourroux et al. 2000).

Studies examining coregulator expression in the ovary are limited (Hlaing et al. 2001, Zhang et al. 2003, Hussein-Fikret \& Fuller 2005, Chen et al. 2008). It is possible that altered coregulator expression may lead to altered transcriptional activation of steroid receptors, with changes in the steroid-mediated actions in follicular development. In this context, NCOAs are overexpressed in some endocrine-dependent organs and tumors and enhance cell proliferation and differentiation (Sarvilinna et al. 2006, Mukherjee et al. 2007), indicating an important pathophysiological role. Also, coactivator expression is known to be sexually dimorphic (Auger et al. 2002, Charlier et al. 2002, Duncan \& Carruth 2007) and regulated by steroid hormones (Murphy \& Segal 1997, Mitev et al. 2003, Charlier et al. 2006). However, there are limited data regarding the expression of coregulators in the bovine ovary (Hlaing et al. 2001), and no studies have been performed to investigate protein localization in different ovarian compartments.

Based on these observations, we hypothesized that cattle with COD may have a disrupted expression of ovarian steroid receptors and their coregulators associated with an altered follicular dynamic and cellular differentiation. As steroid hormones are important intra-ovarian regulators of follicular development and
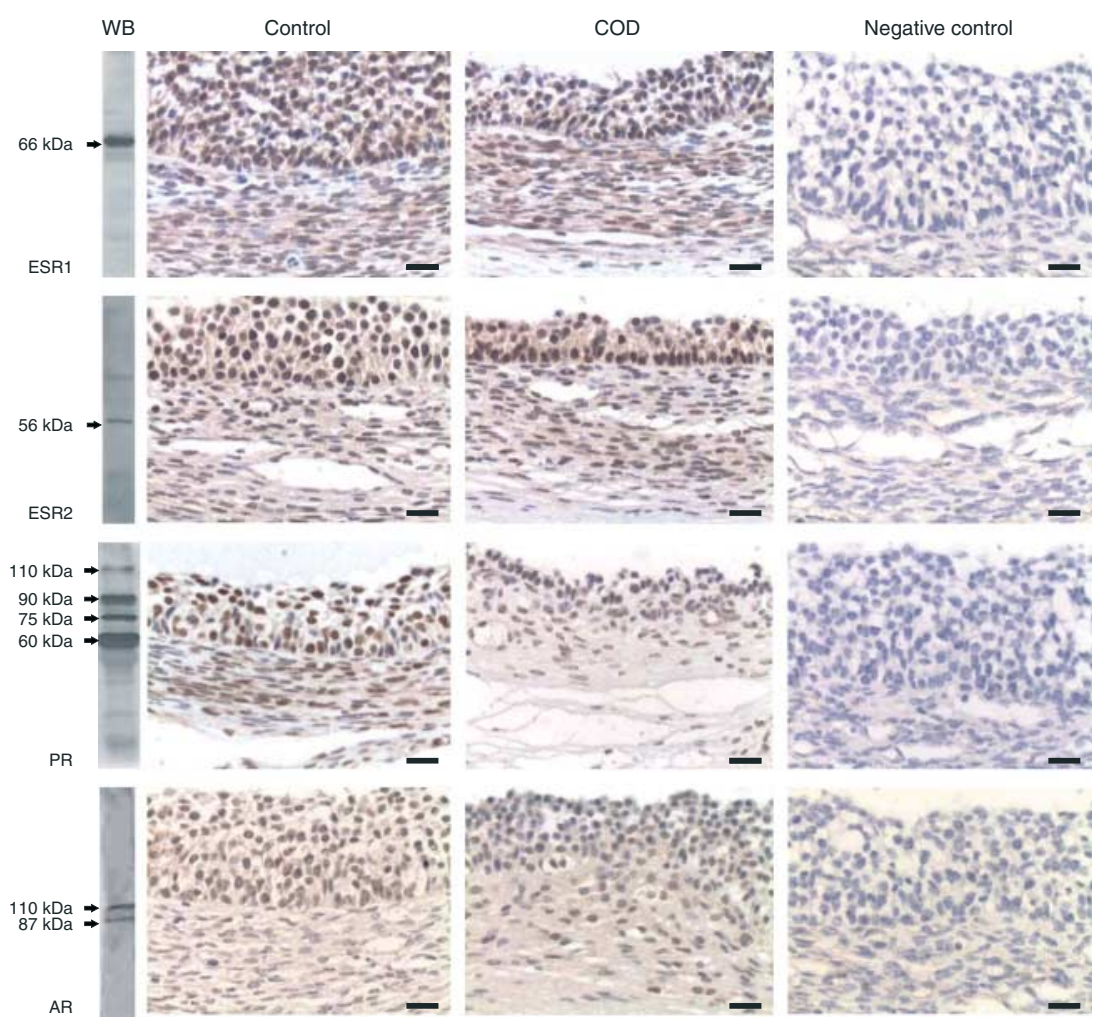

Figure 1 Representative images of ESR1, ESR2, $P G R$, and $A R$ immunostaining in antral follicles of normal cycling animals and cystic follicles of COD-induced animals. Negative controls demonstrating the specificity of the antibody are also shown. Verification of antibody specificity by western blot analyses of ovarian homogenate is shown on the left column. Bars $=20 \mu \mathrm{m}$. 
ovulatory processes, the aim of this study was to determine the protein expression profiles of steroid receptors, NCOA3, NCOR2, and PHB2 in ovarian follicles in an experimental model of COD compared with heifers with regular estrous cycles in order to investigate the mechanisms underlying follicular cyst formation.

\section{Results}

\section{Experimental model}

The successful induction of COD was confirmed by ultrasonography, ovarian morphology, and intrafollicular and serum hormone levels. All the treated animals showed healthy developing follicles, as well as follicles showing different degrees of atresia and one large cyst (in one ovary) with a complete granulosa cell layer. Corpora lutea were absent in all cases. The ovaries from control animals exhibited follicles in various stages of development, including primary, secondary, and tertiary follicles, as well as atretic follicles and corpora lutea. In addition, COD induction was confirmed by serum and follicular fluid hormone analysis. Steroid concentrations in follicular fluid showed that all follicles were categorized as estrogen-active with no differences in estrogen concentrations between cystic and preovulatory (control). Mean progesterone concentrations were significantly higher in the follicular fluid of preovulatory follicles than in induced cysts. The progesterone:estradiol ratio did not differ between cystic and preovulatory follicles (parallel study, Ortega et al. (2008) and Salvetti (2010)).

\section{Antibody specificity}

The results from western blot analysis of follicular wall homogenates are summarized in Figs 1 and 2. Western blot analysis showed positive bands of appropriate molecular weight for each of the proteins studied. The ESR1 and ESR2 antibodies detected a single band at 66 and $55 \mathrm{kDa}$ respectively. Progesterone receptor (PGR) showed three isoforms corresponding to PGRB (116 kDa), PGRA (94 kDa), and PGRC (60 kDa). Androgen receptor $(A R)$ antibody detected a band at $110 \mathrm{kDa}$ (ARA) and another band at $87 \mathrm{kDa}(\mathrm{ARB})$. The NCOA3, NCOR2, and PHB2 antibodies each detected a single band at 160, 150, and $37 \mathrm{kDa}$ respectively corresponding to the expected molecular weights of the coregulatory proteins. In the absence of the primary antibodies, no specific bands were detected.

\section{Immunohistochemistry}

To obtain information regarding the localization of steroid receptors and coregulatory proteins in different follicular structures, their expression was evaluated by immunohistochemistry and quantitative image analysis. In this sense, immunohistochemistry is currently the only technique that allows an integrative analysis about the cellular localization of proteins in nearby tissue compartments when it is not possible to separate cell populations to perform other, more sensitive and specific techniques. This technique also allows determining the location within an integrated context.

\section{Steroid receptor expression}

Expression of ESR1 was localized to the nucleus of the granulosa cells of primary follicles and to both the theca interna and the granulosa cells of secondary follicles (Fig. 3). The intensity of ESR1 staining in the nuclei of granulosa cells was greater than that in theca cells $(P<0.05)$. The immunostaining was increased as the follicular development progressed in the granulosa and theca cell compartment $(P<0.05)$. The immunostaining

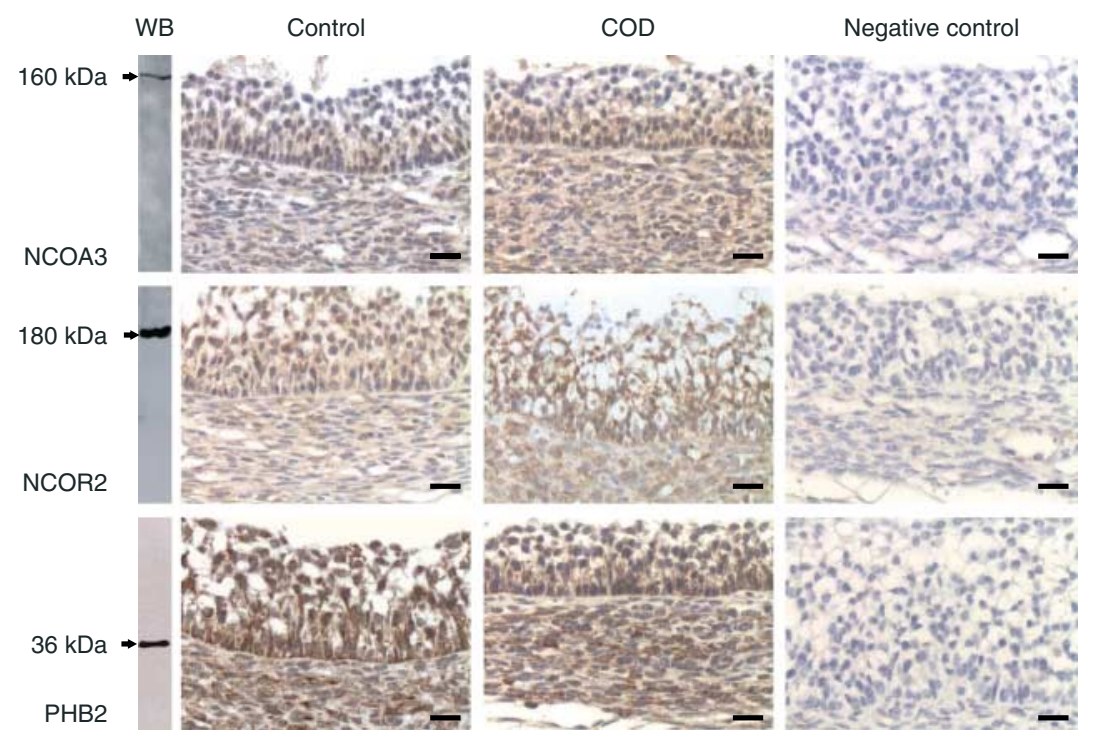

Figure 2 Representative images of NCOA3, NCOR2, and $\mathrm{PHB} 2$ immunostaining in antral follicles of normal cycling animals and cystic follicles of COD-induced animals. Negative controls demonstrating the specificity of the antibody are also shown. Verification of antibody specificity by western blot analyses of ovarian homogenate are shown on the left column. Bars $=20 \mu \mathrm{m}$. 


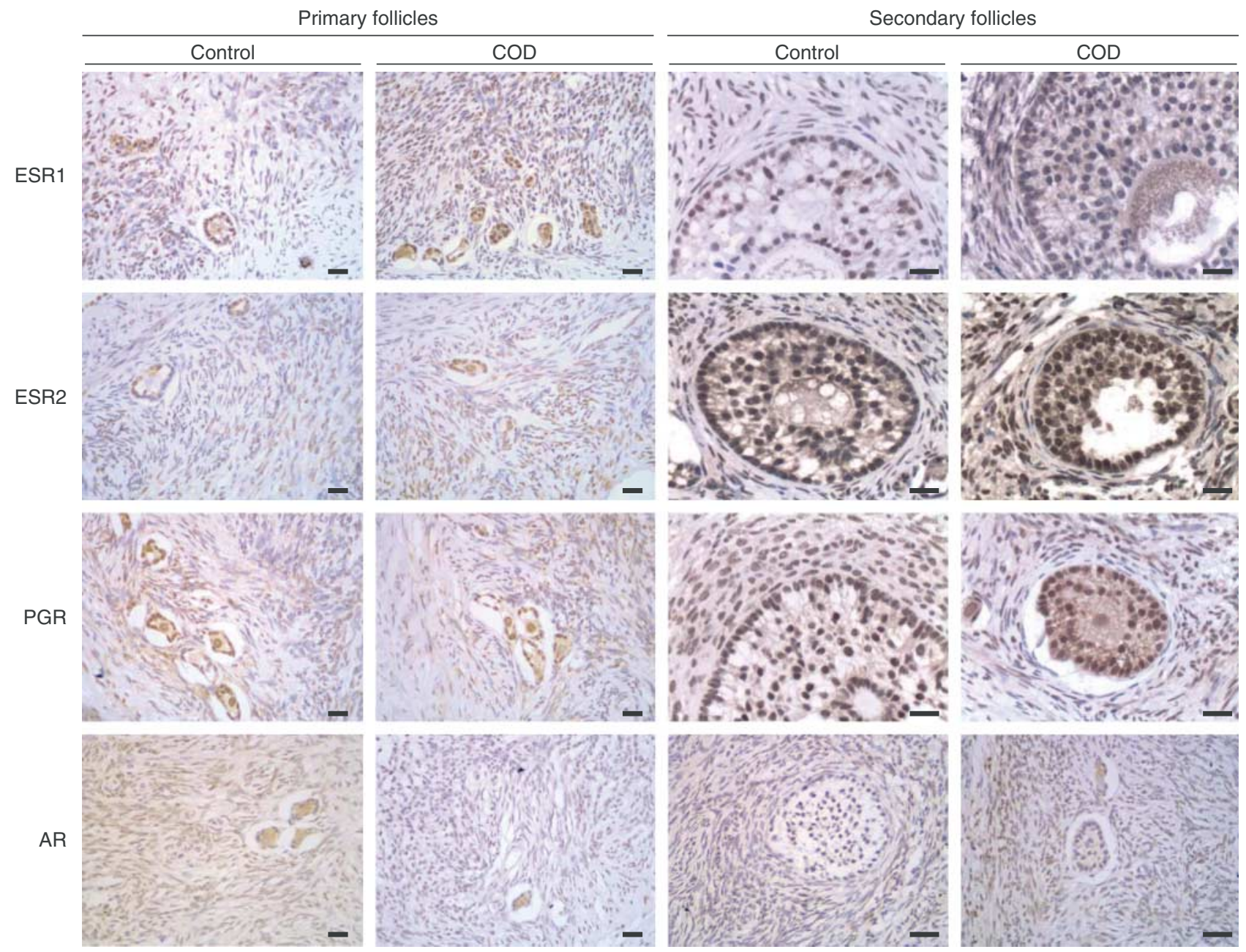

Figure 3 Representative images of ESR1, ESR2, PGR, and AR immunostaining in primary and secondary follicles of normal cycling and COD-induced animals. Bars $=20 \mu \mathrm{m}$.

in cystic follicles was similar to that in tertiary follicles, without differences in the same follicular categories between groups (Figs 1 and 4).

ESR2 was detected in the nucleus of granulosa and theca cells of all the follicular categories studied, and the intensity of immunostaining was higher in the granulosa cells of tertiary follicles than in those of the primary and secondary follicles $(P<0.05$; Figs 1,3 and 4$)$. In animals with induced COD, the immunoexpression of ESR2 was diminished in the tertiary and cystic follicles in relation to that in the tertiary follicles from control animals $(P<0.05$; Fig. 4). Theca cells were scarcely stained, but the tertiary follicles and cysts from COD animals were less stained in theca interna than tertiary follicles from normal animals $(P<0.05$; Figs 1,3 and 4$)$.

PGR was observed in both the nucleus and the cytoplasm of granulosa cells. Maximum staining intensity was observed in tertiary follicles $(P<0.05)$. The expression of PGR was lower in the granulosa cell layer of cystic follicles than in that of the tertiary follicles $(P<0.05)$. The level of immunostaining in theca cells was lower than that in granulosa cells $(P<0.05)$, and no difference was evident across the different follicle stages (Figs 1, 3 and 4).

AR was localized in the nucleus, with predominant expression in granulosa cells and weak staining in theca cells. The intensity of immunostaining for $A R$ was lower in both cysts and tertiary follicles from cows with induced COD than in tertiary follicles from control cows $(P<0.05$; Figs 1, 3 and 4$)$.

\section{Coregulatory expression}

Representative members of the steroid receptor coregulator families, NCOA3, NCOR2, and PHB2, were chosen and their expression was evaluated by immunohistochemistry and quantitative image analysis. Immunostaining of NCOA3 was primarily found in the nucleus and cytoplasm of granulosa and differentiated theca cells, whereas its expression was significantly weaker in theca cells of secondary follicles and theca externa of tertiary follicles than other structures $(P<0.05$; Figs 2 and 5$)$. The most 


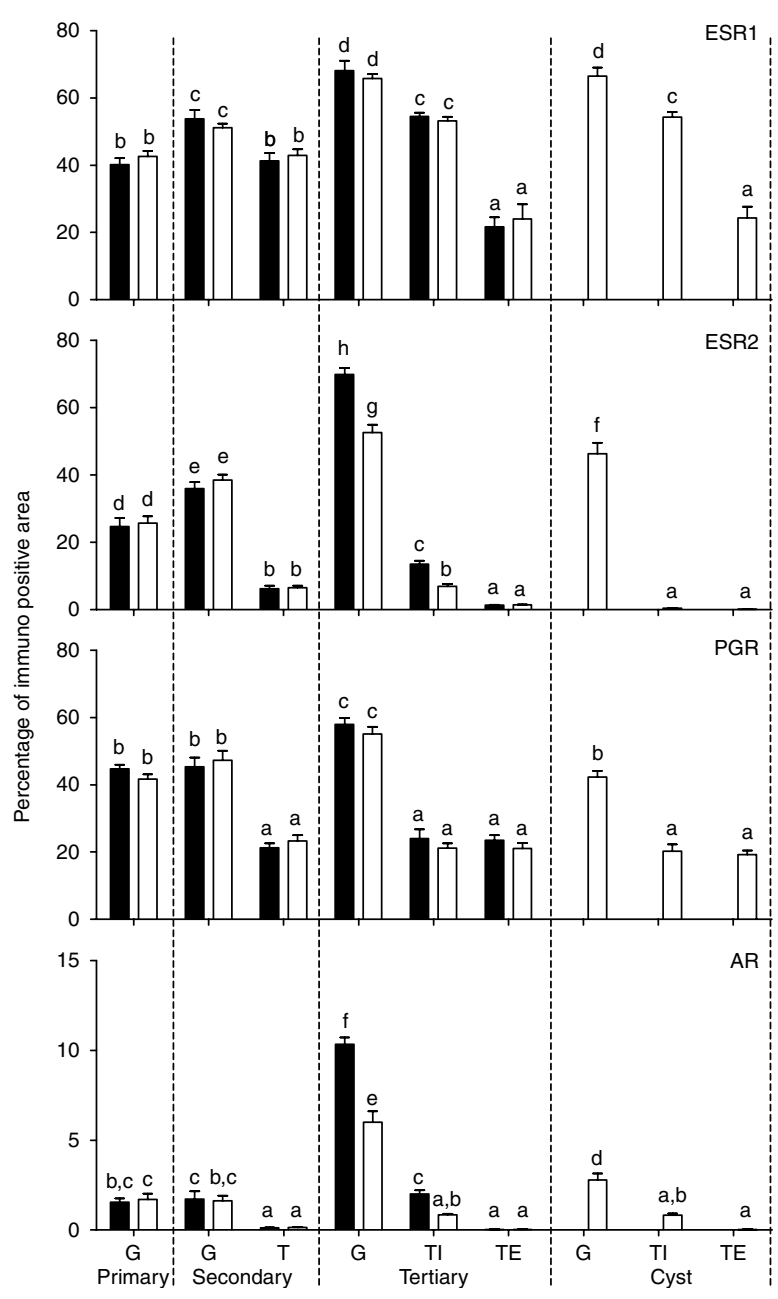

Figure 4 Relative expression (measured as percentage of immunopositive area) of steroid receptors in primary, secondary, tertiary, and cystic follicles of control (black bars) and COD-induced animals (open bars). Significant differences are shown by differing letters. Bars with different superscript letters show significant differences. Values represent the mean \pm s.E.M. G, granulosa cells; T, theca cells; $\mathrm{TE}$, theca externa; $\mathrm{TI}$, theca interna.

intense immunostaining was observed in the theca interna of cystic follicles $(P<0.05$; Fig. 6).

A moderate nuclear and cytoplasmic (perinuclear) expression of NCOR2 was observed in granulosa cells, with a significant increase from primary to tertiary follicles $(P<0.05$; Figs 2, 5 and 6). The theca cells showed a weak immunostaining. In cystic follicles, a high level of cytoplasmic and nuclear immunostaining was evident in both granulosa and theca cell layers compared with other follicle categories ( $P<0.05$; Figs 2, 5 and 6$)$.

Immunostaining for PHB2 was intense in both the perinuclear cytoplasm and the nucleus in granulosa cells from follicles at all stages of development. Staining was much less intense in thecal tissue. There were no differences in staining intensity among groups (Figs 2, 5 and 6).

\section{Discussion}

This study is the first to describe the immunolocalization of steroid receptor coregulators in ovarian follicles during normal and cystic follicular growth in cows. The significance of the changes in the cell type-specific expression pattern of steroid receptors and their coregulators is discussed below.

With the increase in the size of the follicles, the immunostaining of both ESR subtypes in the granulosa cell compartment increased significantly, in agreement with previous observations in cattle and other species (Berisha et al. 2000, Cárdenas et al. 2001, Salvetti et al. 2007). However, no changes were found in the immunoexpression of ESR1 in granulosa or theca cells in any follicular stage of induced cystic ovaries in relation to the control group, and a decrease in the expression of ESR2 was evident in the granulosa and theca interna of tertiary and cystic follicles of the induced COD group. These results agree with the protein and mRNA ESR2 expression patterns previously obtained in cows with COD (Salvetti et al. 2007, Alfaro et al. 2012). However, these reports also describe a concomitant increase in ESR1 expression that was not found in this experimental model. It can be assumed that these differences are due to the evolution of the cysts, taking into account the fact that this is the first article about steroid receptor expression, using an experimental model instead of spontaneous cases.

The differences observed between cystic and tertiary follicles from control heifers may be attributed to follicle age and unrelated to cyst formation. However, numerous studies have shown that cysts are not simply inactive persistent structures but are in fact the contrary, still evolved, with important metabolic activity and structural changes (Calder et al. 2001, Monniaux et al. 2008, Ortega et al. 2008, Grado-Ahuir et al. 2011, Rodríguez et al. 2011). Also, other authors have found similar changes in the protein and mRNA expression of ESR2 isoforms in follicular cysts in women with polycystic ovary syndrome compared with normal size-matched follicles in healthy women (Jakimiuk et al. 2002), and in prenatal testosterone-treated ovine females characterized by follicular persistence (Ortega et al. 2009).

Although ESR1 and ESR2 bind to endogenous ligands such as 17 - $\beta$-estradiol with similar affinity and form homo- and heterodimers, they display differential transcriptional activities in a cell- and promoter context-dependent manner (Mclnerney et al. 1998, Pettersson et al. 2000). Thus, the differential production of ESR2 will likely provide a cellular microenvironment that regulates the estrogen responsiveness of target genes in a cell-dependent manner (O'Brien et al. 1999). As a result, small changes in the ER subtypes ratio may perturb normal follicular development (Mosselman et al. 1996, Pettersson et al. 1997), including alterations in the balance of proliferation/apoptosis, the expression of 


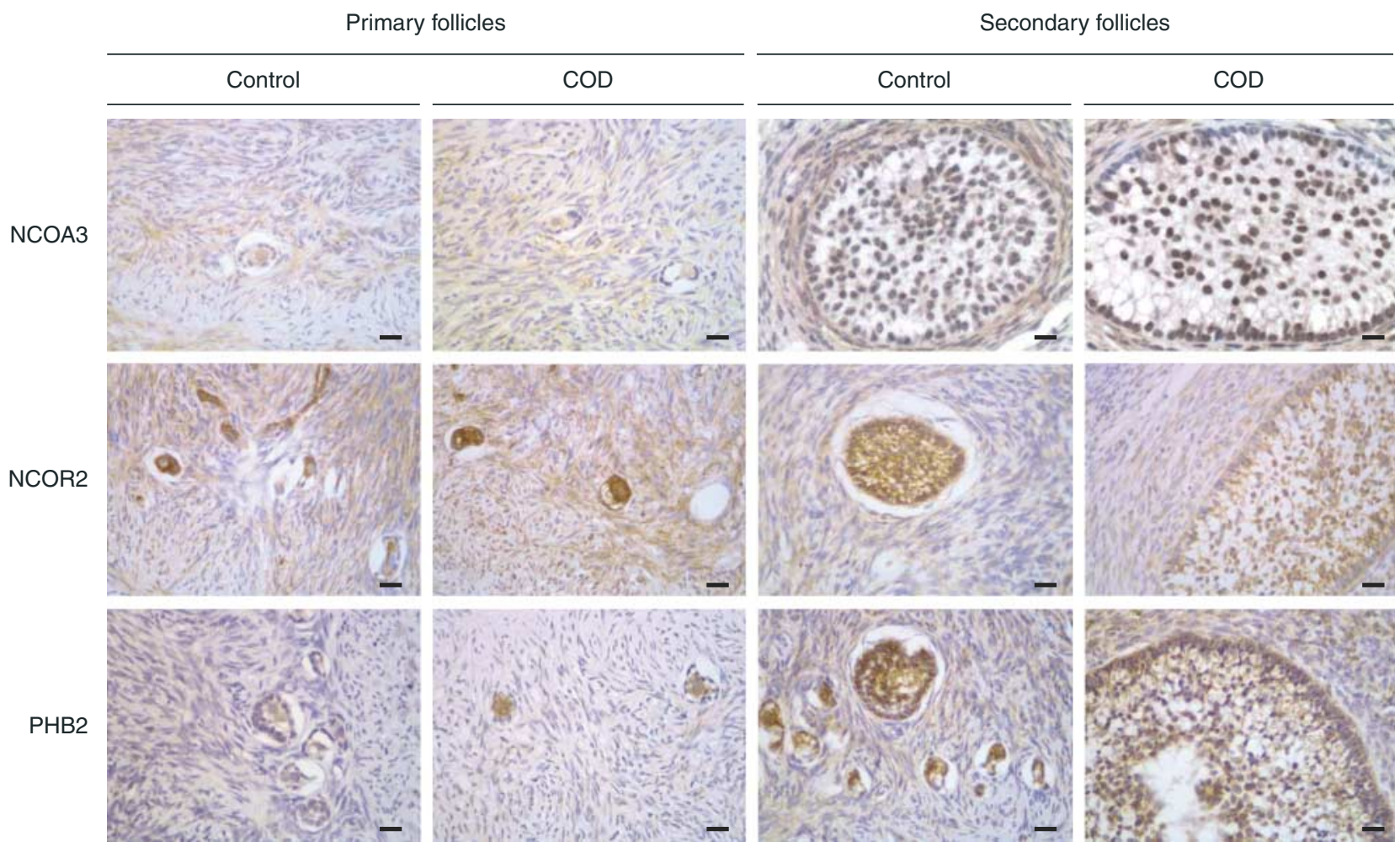

Figure 5 Representative images of NCOA3, NCOR2, and PHB2 immunostaining in primary and secondary follicles of normal cycling and COD-induced animals. Bars $=20 \mu \mathrm{m}$.

gonadotropin receptors, and the disturbance of enzyme action and metabolism, all of which are signs of COD (Calder et al. 2001, Isobe \& Yoshimura 2007, Salvetti et al. 2010).

It has been shown that $A R$ mRNA is expressed in bovine follicles, and it has been suggested that it increases during early follicle development (Hampton et al. 2004). A significant increase in $A R$ mRNA in the granulosa cells of cystic follicles (Alfaro et al. 2012) has been associated with androgens playing a role in follicular differentiation and growth (Hillier \& Tetsuka 1997, Vendola et al. 1998, Walters et al. 2008). Although the results of this study do not agree with these findings, the discrepancy between the mRNA and protein expression levels could be due to posttranslational regulation of protein expression (Sette et al. 2010).

We observed a clear decrease in AR expression in tertiary and follicular cysts in animals with COD. In early stages of follicular development, it has been described that androgen synergistically enhances FSH-induced P450aromatase expression, through its receptors predominantly located in granulosa cells of preantral and early antral follicles. As follicular differentiation progresses, the expression of P450aromatase in preovulatory follicles increases in response to increasing stimulation by gonadotropins, whereas the expression of AR decreases, taking to androgens mainly as a substrate for estrogen synthesis. For healthy follicular development, a smooth transition of androgen utilization from action (via AR) to metabolism (via P450aromatase) is necessary (Tetsuka \& Hillier 1997). The decrease in AR lead to a greater proportion of androgens (testosterone) for the aromatization in granulosa cells with the resulting increase in follicular and circulating estrogens, as observed in ACTH-induced PCO experimental model (Dobson et al. 2000, Salvetti 2010).

Previous studies have shown that growing and cystic follicles from COD animals show a decrease not only in proliferation but also in apoptosis in situ, and the expression of pro-apoptotic genes in relation to the antiapoptotic ones (Salvetti et al. 2009a, 2010). It is known that alterations in the proliferation of granulosa cells and the fate of the follicles, atresia or formation of cysts, are related to multiple growth factors and hormones (gonadotropins and steroid hormones), and specifically, to steroid hormones. The altered equilibrium of ESR1 to ESR2 and an altered AR expression in cystic follicles might be factors contributing to the development of follicular persistence (Ortega et al. 2008, Salvetti et al. 2010).

In this sense, estrogens act through two major receptor subtypes, which associate to form homo- or heterodimers. Although ESR1 homodimers induce increased transcriptional activity in relation to ESR1/ESR2 heterodimers or ESR2 homodimers, and given that we have observed a decrease in the latter subtype in tertiary and 


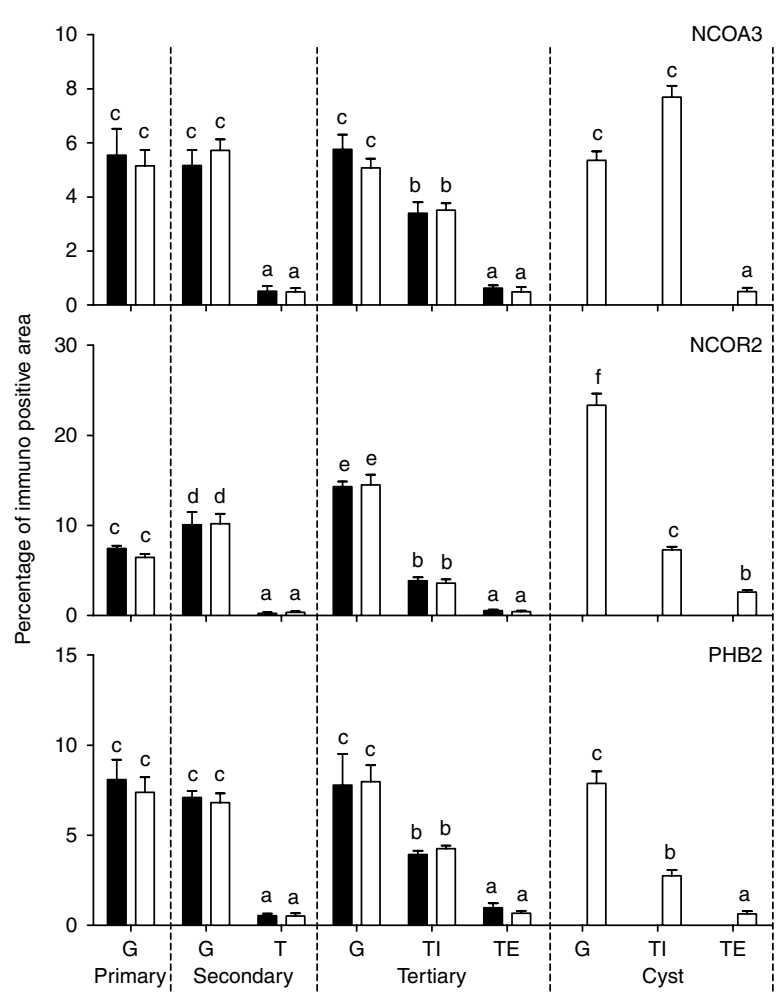

Figure 6 Relative expression (measured as percentage of immunopositive area) of coregulatory proteins in primary, secondary, tertiary, and cystic follicles of control (black bars) and COD-induced animals (open bars). Significant differences are shown by differing letters. Bars with different superscript letters show significant differences. Values represent the mean \pm s.E.M. G, granulosa cells; T, theca cells; $T E$, theca externa; $\mathrm{Tl}$, theca interna.

cystic follicles in animals with COD, it could be inferred that there is greater activation of estrogen-dependent genes in ovarian follicles from these animals. This would lead to a decrease in the rates of apoptosis and increased cell proliferation. Now, while apoptosis levels are decreased in the ovaries of animals with COD, proliferation is also lower (Isobe \& Yashimura 2007, Salvetti et al. 2010). This could be explained by the concomitant changes found in this work in coregulatory proteins, as well as in many other factors regulating folliculogenesis such as insulin-like growth factor 1 (IGF1), IGF2, and gonadotropins (Ortega et al. 2008, Rey et al. 2010, Rodríguez et al. 2011).

Different studies have demonstrated a cell-specific expression of PGR in the bovine ovary (Jo et al. 2002, Van den Broeck et al. 2002b). However, there is disagreement as to its expression in ovarian cysts. Salvetti et al. (2007) showed that no changes were observed in PGR protein expression in cystic follicles, whereas Alfaro et al. (2012) described a higher expression of $P G R$ mRNA, particularly the $\mathrm{B}$ isoform, in the theca cells of cystic follicles compared with healthy follicles. It was found that protein expression diminished in the granulosa cells, while it remained constant in theca cells. These differences with other studies may be due to the specificity of the antibody used in previous immunohistochemistry studies, which did not detect all the isoforms. Also, the sensitivity of PCR, the posttranslational regulation of protein expression, and the length of persistence of the cysts studied may be other factors contributing to these discrepancies (Anderson et al. 1992, Garverick 1997, Sette et al. 2010). The evaluation by western blot analysis of PGR isoforms in complete follicular wall showed a decrease in the expression of the isoform A2 in cystic follicles induced by ACTH in relation to normal large antral follicles without changes in the isoform $B$ between these categories (Salvetti 2010). However, studies in an experimental model of PCOD in rats showed an increase in the ovarian expression of isoform $A$, without changes in isoform B (Salvetti et al. 2009b). There is probably an alteration in the balance PGRA/PGRB leading to alterations in the action of progesterone on follicles in these animals.

Animals with COD usually present high levels of circulating estrogen and LH (Dobson et al. 2000, Vanholder et al. 2006), which could cause alterations in PGR expression (Alfaro et al. 2012). The fact that the expression pattern seen in the normal ovary becomes disrupted in ovarian pathologies and the predominance of one PGR isoform seen in ovarian disease (Graham \& Clarke 2002, Alfaro et al. 2012) suggest that changes in the ratio of PGR isoform expression could regulate the biological activity of progesterone, thereby resulting in functional hormone withdrawal in the absence of changes in serum concentrations or total progesteronebinding activities of the reproductive tissues (Schams et al. 2003, Amrozi et al. 2004, Goldman et al. 2005).

In this study, the first evidence for the presence of steroid receptor coregulatory proteins in the ovary of cows is presented, and their localization is described in the follicular compartments. Granulosa cells of different follicle stages showed an intense immunostaining of NCOA3, while there was a significant increase in its expression in theca interna of cystic follicles. A similar expression pattern was observed for PHB2, except that it did not show an increase in the theca interna of cystic follicles. On the other hand, NCOR2 showed a gradual increase in its expression associated with follicular development, with a higher expression in cystic follicles. In domestic animals, Hlaing et al. (2001) analyzed the presence and distribution of mRNAs encoding several transcriptional cofactors in the ovary of sheep, cows, and pigs. Using northern blotting, the expression of NCOA1, NCOA2, NCOA3, EP3OO (P300), NRIP1 (RIP140), SPA, and NCOR2 mRNA was determined in the ovaries of all the three species. In addition, by in situ hybridization, NCOA1, NRIP1, and SPA were localized in ovarian granulosa, theca, and stromal cells of the sheep ovary (Hlaing et al. 2001). 
Despite its importance, the functional regulation of coregulatory proteins remains poorly understood within an ovarian physiological context. Altered coregulator expression levels, such as the overexpression of coactivators, may lead to the increased transcriptional activation of steroid receptors, with an enhanced response in hormone-dependent growth. The levels of coregulator gene expression in ovarian structures have not been fully characterized. An amplification of NCOA3 has been observed in ovarian tumors and was associated with cell differentiation and growth (Bautista et al. 1998, Tanner et al. 2000, Hussein-Fikret \& Fuller 2005). Also, in breast cancer, the amplification of NCOA3 correlates with high expression levels, increased tumor sizes, and ER and PGR positivity, supporting the role of this coactivator in the development and progression of ER-dependent tumors (Anzick et al. 1997, Bautista et al. 1998). Mice bearing a homozygous deletion of NCOA1 exhibit partial resistance to multiple hormones including estrogen, progesterone, androgen, and thyroid hormones (Edwards 2000), suggesting that different members of the p160 family have overlapping redundant functions that may affect multiple hormonal responses. On the other hand, PHB2 differs from other coregulators in that it is ER selective among the nuclear hormone receptors, acting as a negative feedback regulatory mechanism to control ER-dependent gene expression in normal cells (Mussi etal. 2006). However, in this study, no significant differences in its expression were observed in cystic ovaries.

Although the genes encoding NCOR2 are ubiquitously expressed, their levels are variable across various tissues and cell lines, including ovarian tumors (Havrilesky et al. 2001). We found that NCOR2 expression was higher in granulosa cells than in theca cells with a significant increase from primary to tertiary follicles. However, a significant upregulation in the expression of NCOR2 was found in the theca and granulosa cells of cystic ovaries compared with that observed in the normal ovary. The findings suggest that NCOR2 could have a role as a corepressor of estrogen, androgens, and progesterone in the cystic ovary, modulating the response to steroid hormones in the microenvironment affected by the imbalance in the steroid receptor expression. We found an increase in the expression of NCOR2 in granulosa and theca cells of follicular cysts, concomitantly with an increase in the expression of NCOA3 in the theca interna of cysts. Both coregulatory proteins act on the transcriptional activity of various ligand-dependent transcriptional activators, including androgen and ESRs. Considering the overall regulatory balance, we can assume that there is a higher transcriptional activity of estrogen and androgen-dependent genes via ESR1 and AR receptors respectively in the theca interna cells of follicular cysts, which would be diminished in the granulosa due to increased expression of corepressor NCOR2. This would explain that observed previously in relation to the increase in cell differentiation of theca cells, which in many cases are luteinized in follicular cysts, and the decreased levels of apoptosis, factors that contribute to persistent follicles in animals with COD (Ortega et al. 2007a, 2007b, 2008, Rey et al. 2010, Salvetti et al. 2010, Velázquez et al. 2010, 2011).

Although this study was not designed to directly determine the role of steroid receptor cofactors in the COD, the results indicate that cofactors may be involved in altered folliculogenesis, ovulation, differentiation, and follicular persistence as a component of the pathogenesis in ovarian alterations in cattle. In summary, the results of this study are the first evidence for the presence of steroid receptor coregulatory proteins in cows with COD. Furthermore, variation in the relative levels and pattern expression of ESR and AR was observed in ovarian compartments associated with an experimental model of COD. While the findings of the current study provide evidence that an altered steroid signaling system may be present in bovine cystic follicles, additional studies are necessary to understand the potential associations with other follicular regulators.

\section{Materials and Methods}

\section{Animals and treatment}

All the procedures were approved by the Institutional Ethics and Security Committee (Faculty of Veterinary Sciences, Universidad Nacional del Litoral, Argentina) and are consistent with the Guide for the Care and Use of Agricultural Animals in Agricultural Research and Teaching (Federation of Animal Science Societies, 1999). Ten nulliparous Argentinean Holstein heifers (18-24 months old; 400-450 kg body weight; maintained under standard husbandry conditions) with regular estrous cycles, previously corroborated by detection of estrus, rectal palpation, and ultrasonography, were used. The estrous cycles were synchronized using the OVSYNCH protocol: the animals were injected with GNRH (Receptal, Intervet, Buenos Aires, Argentina, $4 \mu \mathrm{g} / \mathrm{ml}, 5 \mathrm{ml} /$ animal) on day 0, prostaglandin $\mathrm{F}_{2 \alpha}$ (lliren, Intervet, $0.2 \mathrm{mg} / \mathrm{ml}, 5 \mathrm{ml} /$ animal) on day 7 , and $\mathrm{GNRH}$ on day 9 . Observations for estrus began $24 \mathrm{~h}$ after the second GNRH treatment and were made every $12 \mathrm{~h}$. The time of the first detection of estrous behavior was designated day 0 of the estrous cycle (Gumen et al. 2003).

Beginning on day 15 of a synchronized estrous cycle, five heifers received s.c. injections of $1 \mathrm{mg} / \mathrm{ml}$ ( $1 \mathrm{ml} /$ animal) tetracosactrin hexaacetate (Synacthen Depot, Novartis), a synthetic polypeptide with ACTH activity, every $12 \mathrm{~h}$ for 7 days. Five control animals received saline $(1 \mathrm{ml}$; Dobson et al. 2000, Ortega et al. 2008, Salvetti et al. 2010). Ovarian ultrasonographic examinations were performed in all animals as described previously, using a real-time, B-mode scanner equipped with a $7.5 \mathrm{MHz}$, linear-array, intrarectal transducer (Aloka, SSD 500; Wallingford, CT, USA; Sirois \& Fortune 1988). The growth and regression of follicles $>5 \mathrm{~mm}$, corpora lutea, and cysts were monitored and daily ovarian ultrasonography 
was performed through a complete estrous cycle (21-23 days in the control group) and from day 14 (day 0 , day of estrus) until day 48 (treated group). Cysts were detected in all animals by ultrasonography and defined as any follicular structure with a diameter equal to or $>20 \mathrm{~mm}$ present for 10 days or more, without ovulation or corpus luteum $(\mathrm{CL})$ formation (Dobson et al. 2000). The first day of cyst formation was the day a follicle attained a diameter of $20 \mathrm{~mm}$ or more, and the ovaries were removed 10 days later by flank laparotomy. In the heifers used as controls, ovariectomy was conducted when the dominant follicle reached a diameter $>10 \mathrm{~mm}$, in the absence of an active $\mathrm{CL}$, to obtain normal growing follicles (approximately day 18). Blood samples were centrifuged at $1000 \mathrm{~g}$ for $30 \mathrm{~min}$ and serum was stored at $-20{ }^{\circ} \mathrm{C}$ until hormone analysis (data not shown; parallel study, Ortega et al. (2008)).

\section{Tissue sampling and classification of follicles}

During the macroscopic examination of the ovaries, the external follicular diameter was measured with calipers to corroborate ultrasound measurements, and follicular fluid from each follicle was aspirated and stored separately at $-20^{\circ} \mathrm{C}$. Small samples from ovarian tissues of each group were immediately frozen at $-80{ }^{\circ} \mathrm{C}$ until used in western blotting for the determination of the specificity of the antibodies used in immunohistochemistry. The health status of the follicles was confirmed by hormonal concentrations (relation estrogen:progesterone) in follicular fluid (Ortega et al. 2008, Salvetti 2010).

After taking follicular fluid and small samples for molecular biology techniques, ovaries were fixed in $4 \%$ buffered formaldehyde for $8 \mathrm{~h}$ at $4{ }^{\circ} \mathrm{C}$ and then washed in PBS. For light microscopy, fixed tissues were dehydrated in an ascending series of ethanol, cleared in xylene, and embedded in paraffin. Sections (5 $\mu \mathrm{m}$ thick) were mounted on slides previously treated with 3-aminopropyltriethoxysilane (Sigma-Aldrich) and primarily stained with hematoxylin-eosin for a preliminary observation of all ovarian structures (Ortega et al. 2008, Salvetti et al. 2010). For the immunohistochemical studies, follicles were classified into the following groups: primary, secondary, tertiary, and cystic follicles (Silvia et al. 2002, Ortega et al. 2008, Salvetti et al. 2010). Primary follicles were composed of one oocyte surrounded by one cuboid granulosa cell layers, without an antrum. Secondary follicles were composed of one oocyte surrounded by two or more granulosa cell layers, without an antrum. Tertiary follicles were composed of one oocyte surrounded by a stratified epithelium of granulosa cells (cumulus oophorus) with the follicular antrum present and with a size range of $3-9 \mathrm{~mm}$ without signs of apoptosis in their granulosa (Jaiswal et al. 2004, D'Haeseleer et al. 2005, Adams et al. 2008). Only cystic follicles with a complete granulosa cell layer within the sections examined and without signs of luteinization were used.

\section{Antibodies}

Antibodies for steroid receptors were purchased from commercial sources, as listed in Table 1. To evaluate steroid receptor coregulator expression, affinity-purified rabbit polyclonal antibodies provided by Dr J G Ramos (Laboratorio de
Table 1 Antibodies, suppliers, and dilutions used for immunohistochemistry $(\mathrm{IH})$ and western blotting $(\mathrm{WB})$.

\begin{tabular}{|c|c|c|}
\hline Antibodies & Clone/source & Dilution \\
\hline $\begin{array}{l}\text { Primary antibodies } \\
\text { ESR1 }\end{array}$ & $\begin{array}{l}\text { Clone 1D5 (BioGenex, } \\
\text { San Ramon, CA, USA) }\end{array}$ & $\mathrm{IH}: 1: 40$ \\
\hline ESR2 & Polyclonal. (BioGenex) & $\begin{array}{l}\text { WB: } 1: 50 \\
\text { IH: } 1: 250 \\
\text { WB: } 1: 500\end{array}$ \\
\hline PGR & Clone PR88 (BioGenex) & $\begin{array}{l}\text { IH: } 1: 40 \\
\text { WB: } 1: 100\end{array}$ \\
\hline AR & $\begin{array}{l}\text { Polyclonal (Affinity } \\
\text { BioReagents, Golden, } \\
\text { CO, USA) }\end{array}$ & $\mathrm{IH}: 1: 40$ \\
\hline NCOA3 & $\begin{array}{l}\text { Polyclonal (provided by } \\
\text { Dr J G Ramos) }\end{array}$ & $\begin{array}{l}\text { WB: } 1: 50 \\
\mathrm{IH}: 1: 50\end{array}$ \\
\hline NCOR2 & $\begin{array}{l}\text { Polyclonal (provided by } \\
\text { Dr J G Ramos) }\end{array}$ & $\begin{array}{l}\text { WB: } 1: 50 \\
\mathrm{IH}: 1: 40\end{array}$ \\
\hline PHB2 & $\begin{array}{l}\text { Polyclonal (provided by } \\
\text { Dr J G Ramos) }\end{array}$ & $\begin{array}{l}\text { WB: 1:50 } \\
\text { IH: 1:100 }\end{array}$ \\
\hline Secondary antibodies & & WB: 1:100 \\
\hline $\begin{array}{l}\text { Biotinylated anti-rabbit } \\
\text { IgG }\end{array}$ & $\begin{array}{l}\text { Goat polyclonal (Zymed, } \\
\text { San Francisco, CA, } \\
\text { USA) }\end{array}$ & $\mathrm{IH}: 1: 100$ \\
\hline $\begin{array}{l}\text { Biotinylated anti-mouse } \\
\text { IgG }\end{array}$ & $\begin{array}{l}\text { Goat polyclonal } \\
\text { (Chemicon, Temecula, } \\
\text { CA, USA) }\end{array}$ & $\mathrm{IH}: 1: 100$ \\
\hline $\begin{array}{l}\text { Anti-mouse IgG } \\
\text { peroxidase }\end{array}$ & $\begin{array}{l}\text { Goat polyclonal } \\
\text { (GE-Amersham) }\end{array}$ & WB: $1: 500$ \\
\hline $\begin{array}{l}\text { Anti-rabbit } \lg G \\
\text { peroxidase }\end{array}$ & $\begin{array}{l}\text { Goat polyclonal } \\
\text { (GE-Amersham) }\end{array}$ & WB: 1:100C \\
\hline
\end{tabular}

Endocrinología y Tumores Hormonodependientes, Facultad de Bioquímica y Ciencias Biológicas, Universidad Nacional del Litoral, Argentina) were used (Varayoud et al. 2008, Monje et al. 2009). Briefly, the antigens were expressed in Escherichia coli JM109 (Stratagene Corp., La Jolla, CA, USA) as glutathione$S$-transferase fusion proteins, using a pGEX4T-3 vector (Stratagene Corp.). The NCOA3 antigen included the region corresponding to amino acids 581-650 of the rat sequence (accession no. XP_215947), whereas the NCOR2 antigen included amino acids 1946-1995 (accession no. XP_341073) and the PHB2 antigen included amino acids 156-299 (accession no. NM 001013035). The interspecies homology between the target peptide of each antibody and the corresponding bovine protein was tested using Basic Local Alignment Search Tool (BLAST Software; http://www.ncbi.nlm. nih.gov/BLAST) to confirm antigen specificity. Also, the specificity of the antiserum was tested via western blot, as described later.

\section{Immunohistochemistry}

The details, suppliers, and concentrations of the antibodies used are reported in Table 1. Each antibody was assayed in five sections (minimum) of each ovary from each heifer. A streptavidin-biotin immunoperoxidase method was performed as described previously (Salvetti et al. 2004, Ortega et al. 2009). Briefly, after deparaffinization, microwave pretreatment (antigen retrieval) was performed by incubating the 
sections in $0.01 \mathrm{M}$ citrate buffer ( $\mathrm{pH}$ 6.0). The endogen peroxidase activity was inhibited with $3 \%(\mathrm{v} / \mathrm{v}) \mathrm{H}_{2} \mathrm{O}_{2}$ in methanol, and nonspecific binding was blocked with $10 \%(\mathrm{v} / \mathrm{v})$ normal goat serum. All sections were incubated with the primary antibodies for $18 \mathrm{~h}$ at $4{ }^{\circ} \mathrm{C}$ and then for $30 \mathrm{~min}$ at room temperature with biotinylated secondary antibodies selected specifically for each of the two types of primary antibodies used (monoclonal or polyclonal). The antigens were visualized by the streptavidin-peroxidase method (BioGenex, San Ramon, CA, USA), and 3,3-diaminobenzidine (Liquid DAB-Plus Substrate Kit; Zymed, San Francisco, CA, USA) was used as the chromogen. Finally, the slides were washed in distilled water and counterstained with Mayer's hematoxylin, before being dehydrated and mounted.

To verify the immunoreaction specificity, adjacent control sections were subjected to the same immunohistochemical methods, replacing primary antibodies with rabbit and mouse nonimmune sera. The specificity of the secondary antibodies was tested by incubation with the primary antibodies raised against human antigens with a proven negative reaction to the tissues of cattle: anti-CD45 (Clone: PD7/26; Dako, Carpinteria, CA, USA) and anti-Ki-67 (polyclonal, rabbit anti-human Ki-67; Dako). To exclude the possibility of nonsuppressed endogenous peroxidase activity, some sections were incubated with $\mathrm{DAB}$ alone.

\section{Western blotting}

To test the specificity of the primary antibodies, ovarian tissue extracts were separated by SDS-PAGE (15\% resolving gel), as described previously (Ortega et al. 2009, Salvetti et al. 2010). Proteins were transferred onto nitrocellulose membranes (Amersham), blocked for $1 \mathrm{~h}$ in $2 \%$ nonfat milk in Tris-buffered saline containing $0.05 \%$ Tween 20 (Sigma-Aldrich Corp.), and then incubated overnight at $4{ }^{\circ} \mathrm{C}$ with specific primary antibodies (Table 1). Following washing, membranes were treated for $1 \mathrm{~h}$ with the corresponding secondary peroxidaseconjugated antibody (Table 1). The immunopositive bands were detected by chemiluminescence, using the ECL-plus system (GE-Amersham) on hyperfilm-ECL film (GE-Amersham).

\section{Image analysis}

The images were analyzed using the Image Pro-Plus 3.0.1 system (Media Cybernetics, Silver Spring, MA, USA). For the immunohistochemistry technique, images were digitized using a CCD color video camera (Motic 2000, Motic China Group, Xiamen, China) mounted on a conventional light microscope (Olympus BH-2, Olympus Co.), using an objective magnification of $\times 40$. The microscope was prepared for Koehler illumination. This was achieved by recording a reference image of an empty field for the correction of unequal illumination (shading correction) and calibrating the measurement system with a reference slide to determine background threshold values. The reference slides contained a series of tissue sections stained in the absence of a primary antibody. The positive controls were used as interassay controls to maximize the levels of accuracy and robustness of the method (Ranefall et al. 1998, Ortega et al. 2009, 2010).
The methodological details of image analysis as a valid method for quantifying have been described previously (Baravalle et al. 2007, Ortega et al. 2007a, 2007b, 2008, 2009, 2010, Salvetti et al. 2007). The main strength of the imaging approach used in this study is the visualization of the in situ localization of proteins within the cells of interest. The image analysis score was calculated separately in each follicular wall layer (granulosa and theca cells) from at least 50 images of the primary, secondary, and tertiary follicles from ovaries of both groups and cystic follicles from animals with induced COD.

The percentage of the immunopositive-stained area was used to determine protein expression by immunohistochemistry and calculated as a percentage of the total area evaluated through the color segmentation analysis, which extracts objects by locating all objects of the specific color (brown stain). The brown stain was selected with a sensitivity of 4 (maximum 5) and a mask was then applied to separate the colors permanently. The images were then transformed to a bi-level scale TIFF format.

\section{Statistical analysis}

The number of individuals per group was obtained from a sample size calculation that evaluated the number of individuals necessary to produce an estimate of the immunoreactivity that would fall within 0.4 units of the real value. A statistical software package (SPSS 11.0 for Windows, SPSS, Inc., Chicago, IL, USA) was used to perform the statistical tests. The differences between the groups of data were assessed by one-way ANOVA, followed by Duncan's multiple range tests. $P<0.05$ values were considered significant. Results are expressed as mean \pm S.E.M.

In these analyses, the dependent variable was percentage of immunopositive-stained area for each of the seven proteins studied, and the independent variable (fixed factor) was each tissular compartment (treated or not; 15 in total). This comparison among all compartments allowed us to detect changes in the expression of the proteins analyzed not only due to treatment but also due to follicular development and compartments.

\section{Declaration of interest}

The authors declare that there is no conflict of interest that could be perceived as prejudicing the impartiality of the research reported.

\section{Funding}

This study was supported by a grant from the Argentine National Agency for the Promotion of Science and Technology (ANPCyT; PICT 2005-38101; PICT 2010-2315). N R Salvetti and $\mathrm{H} \mathrm{H}$ Ortega are Research Career Members, and $\mathrm{M} \mathrm{M} \mathrm{L}$ Velázquez, A N Amweg, and P U Díaz are Fellows of the National Scientific Research Council (CONICET, Argentina). V Matiller is Fellow of the ANPCyT. 


\section{Acknowledgements}

The authors are grateful to the staff of the Large Animal Health Hospital of the FCV-UNL for the animal care and help with generation of the experimental animals; Drs Juan Cruz Acosta and Lorena Andrea Müller, for assistance with ACTH treatment, and/or collection, processing and sectioning of ovaries. They also thank the staff members of the Laboratory of Cellular Biology (FCV-UNL) for their technical support during processing of the slides and to Novartis Laboratories for the provision of drugs.

\section{References}

Adams GP, Jaiswal R, Singh J \& Malhi P 2008 Progress in understanding ovarian follicular dynamics in cattle. Theriogenology 69 72-80. (doi:10.1016/j.theriogenology.2007.09.026)

Alfaro NS, Salvetti NR, Velázquez MML, Stangaferro ML, Rey F \& Ortega HH 2012 Steroid receptor mRNA expression in the ovarian follicles of cows with cystic ovarian disease. Research in Veterinary Science 92 478-485. (doi:10.1016/j.rvsc.2011.04.009)

Amrozi , Kamimura S, Ando T \& Hamana K 2004 Distribution of estrogen receptor $\alpha$ in the dominant follicles and corpus luteum at the three stages of estrous cycle in Japanese black cows. Journal of Veterinary Medical Science 66 1183-1188. (doi:10.1292/jvms.66.1183)

Anderson E, Lee MT \& Lee GY 1992 Cystogenesis of the ovarian antral follicle of the rat: ultrastructural changes and hormonal profile following the administration of dehydroepiandrosterone. Anatomical Record 234 359-382. (doi:10.1002/ar.1092340307)

Anzick SL, Kononen J, Walker RL, Azorsa DO, Tanner MM, Guan XY, Sauter G, Kallioniemi OP, Trent JM \& Meltzer PS 1997 AIB1, a steroid receptor coactivator amplified in breast and ovarian cancer. Science $\mathbf{2 7 7}$ 965-968. (doi:10.1126/science.277.5328.965)

Auger AP, Perrot-Sinal TS, Auger CJ, Ekas LA, Tetel MJ \& McCarthy MM 2002 Expression of the nuclear receptor coactivator, cAMP response element-binding protein, is sexually dimorphic and modulates sexual differentiation of neonatal rat brain. Endocrinology 143 3009-3016. (doi:10.1210/en.143.8.3009)

Baravalle C, Salvetti NR, Mira GA, Lorente JA \& Ortega HH 2007 Role of ACTH in the pathogenesis of polycystic ovarian syndrome in the rat: hormonal profiles and ovarian morphology. Physiological Research 56 67-78.

Bautista S, Vallès H, Walker RL, Anzick S, Zeillinger R, Meltzer P \& Theillet C 1998 In breast cancer, amplification of the steroid receptor coactivator gene AIB1 is correlated with estrogen and progesterone receptor positivity. Clinical Cancer Research 4 2925-2929.

Berisha B, Schams D, Kosmann M, Amselgruber W \& Einspanier R 2000 Expression and localization of vascular endothelial growth factor and basic fibroblastic growth factor during the final growth of bovine ovarian follicles. Journal of Endocrinology 167 371-382. (doi:10.1677/joe.0. 1670371)

Brosens JJ 2004 Steroid receptor action. Best Practice \& Research. Clinical Obstetrics \& Gynaecology 18 265-283. (doi:10.1016/j.bpobgyn.2004. 01.006)

Calder MD, Manikkam M, Salfen BE, Youngquist RS, Lubahn DB, Lamberson WR \& Garverick HA 2001 Dominant bovine ovarian follicular cysts express increased levels of messenger RNAs for luteinizing hormone receptor and $3 \beta$ hydroxysteroid dehydrogenase delta(4), delta(5) isomerase compared to normal dominant follicles. Biology of Reproduction 65 471-476. (doi:10.1095/biolreprod65.2.471)

Cárdenas H, Burke KA, Bigsby RM, Pope WF \& Nephew KP 2001 Estrogen receptor $\beta$ in the sheep ovary during the estrous cycle and early pregnancy. Biology of Reproduction 65 128-134. (doi:10.1095/biolreprod65.1.128)

Cassar CA, Dow MP, Pursley JR \& Smith GW 2002 Effect of the preovulatory $\mathrm{LH}$ surge on bovine follicular progesterone receptor mRNA expression. Domestic Animal Endocrinology 22 179-187. (doi:10.1016/S07397240(02)00124-8)
Charlier TD, Lakaye B, Ball GF \& Balthazart J 2002 Steroid receptor coactivator NCOA1 exhibits high expression in steroid-sensitive brain areas regulating reproductive behaviors in the quail brain. Neuroendocrinology 76 297-315. (doi:10.1159/000066624)

Charlier TD, Ball GF \& Balthazart J 2006 Plasticity in the expression of the steroid receptor coactivator 1 in the Japanese quail brain: effect of sex, testosterone, stress and time of the day. Neuroscience 140 1381-1394. (doi:10.1016/j.neuroscience.2006.03.002)

Chen JD \& Evans RM 1995 A transcriptional co-repressor that interacts with nuclear hormone receptors. Nature 377 454-457. (doi:10.1038/ 377454a0)

Chen YJ, Lee MT, Yao HC, Hsiao PW, Ke FC \& Hwang JJ 2008 Crucial role of estrogen receptor- $\alpha$ interaction with transcription coregulators in folliclestimulating hormone and transforming growth factor $\beta 1$ up-regulation of steroidogenesis in rat ovarian granulosa cells. Endocrinology 149 4658-4668. (doi:10.1210/en.2008-0063)

Delage-Mourroux R, Martini PGV, Choi I, Kraichely DM, Hoeksema J \& Katzenellenbogen BS 2000 Analysis of estrogen receptor interaction with a repressor of estrogen receptor activity (REA) and the regulation of estrogen receptor transcriptional activity by REA. Journal of Biological Chemistry 275 35848-35856. (doi:10.1074/jbc.M001327200)

D'Haeseleer MM, Van den Broeck WLM \& Simoens P 2005 Localization of estrogen receptor $\beta(E R \beta)$ mRNA within different bovine ovarian follicles. Anatomia, Histologia, Embryologia 34 14. (doi:10.1111/j.1439-0264. 2005.00669 30.x)

Dobson H, Ribadu AY, Noble KM, Tebble JE \& Ward WR 2000 Ultrasonography and hormone profiles of adrenocorticotrophic hormone (ACTH)-induced persistent ovarian follicles (cysts) in cattle. Journal of Reproduction and Fertility 120 405-410. (doi:10.1530/reprod/120. 2.405)

Drummond AE 2006 The role of steroids in follicular growth. Reproductive Biology and Endocrinology 4 16. (doi:10.1186/1477-7827-4-16)

Drummond AE, Britt KL, Dyson M, Jones ME, Kerr JB, O'Donnell L, Simpson ER \& Findlay JK 2002 Ovarian steroid receptors and their role in ovarian function. Molecular and Cellular Endocrinology 191 27-33. (doi:10.1016/S0303-7207(02)00052-7)

Duncan KA \& Carruth LL 2007 The sexually dimorphic expression of L7/SPA, an estrogen receptor coactivator, in zebra finch telencephalon. Developmental Neurobiology 67 1852-1866. (doi:10.1002/dneu. 20539)

Edwards DP 2000 The role of coactivators and corepressors in the biology and mechanism of action of steroid hormone receptors. Journal of Mammary Gland Biology and Neoplasia 5 307-324. (doi:10.1023/ A:1009503029176)

Garverick HA 1997 Ovarian follicular cysts in dairy cows. Journal of Dairy Science 80 995-1004. (doi:10.3168/jds.S0022-0302(97)76025-9)

Goldman S, Weiss A, Almalah I \& Shalev E 2005 Progesterone receptor expression in human decidua and fetal membranes before and after contractions: possible mechanism for functional progesterone withdrawal. Molecular Human Reproduction 11 269-277. (doi:10.1093/ molehr/gah161)

Grado-Ahuir JA, Aad PY \& Spycer LJ 2011 New insights into the pathogenesis of cystic follicles in cattle: microarray analysis of gene expression in granulosa cells. Journal of Animal Science 89 1769-1786. (doi:10.2527/jas.2010-3463)

Graham JD \& Clarke CL 2002 Expression and transcriptional activity of progesterone receptor $\mathrm{A}$ and progesterone receptor $\mathrm{B}$ in mammalian cells. Breast Cancer Research 4 187-190. (doi:10.1186/bcr450)

Gumen A, Guenther JN \& Wiltbank MC 2003 Follicular size and response to Ovsynch versus detection of estrus in anovular and ovular lactating dairy cows. Journal of Dairy Science 86 3184-3194. (doi:10.3168/jds. S0022-0302(03)73921-6)

Hampton JH, Manikkam M, Lubahn DB, Smith MF \& Garverick HA 2004 Androgen receptor mRNA expression in the bovine ovary. Domestic Animal Endocrinology 27 81-88. (doi:10.1016/j.domaniend.2004. 01.005)

Havrilesky LJ, McMahon CP, Lobenhofer EK, Whitaker R, Marks JR \& Berchuck A 2001 Relationship between expression of coactivators and corepressors of hormone receptors and resistance of ovarian cancers to growth regulation by steroid hormones. Journal of the Society for Gynecologic Investigation 8 104-113. (doi:10.1016/S1071-5576(01) 00093-4) 
Hillier SG \& Tetsuka M 1997 Role of androgens in follicle maturation and atresia. Baillière's Clinical Obstetrics and Gynaecology $11249-260$. (doi:10.1016/S0950-3552(97)80036-3)

Hlaing M, Nam K, Lou J, Pope WF \& Nephew KP 2001 Evidence for expression of estrogen receptor cofactor messenger ribonucleic acid in the ovary and uterus of domesticated animals (sheep, cow and pig). Life Sciences 68 1427-1438. (doi:10.1016/S0024-3205(01)00937-7)

Hörlein AJ, Näär AM, Heinzel T, Torchia J, Gloss B, Kurokawa R, Ryan A, Kamei Y, Söderström M, Glass CK et al. 1995 Ligandindependent repression by the thyroid hormone receptor mediated by a nuclear receptor co-repressor. Nature 377 397-404. (doi:10.1038/ 377397a0)

Hussein-Fikret S \& Fuller PJ 2005 Expression of nuclear receptor coregulators in ovarian stromal and epithelial tumours. Molecular and Cellular Endocrinology 229 149-160. (doi:10.1016/j.mce.2004.08.005)

Isobe N \& Yoshimura Y 2007 Deficient proliferation and apoptosis in the granulosa and theca interna cells of the bovine cystic follicle. Journal of Reproduction and Development 53 1119-1124. (doi:10.1262/jrd. 19041)

Jaiswal RS, Singh J \& Adams GP 2004 Developmental pattern of small antral follicles in the bovine ovary. Biology of Reproduction 71 1244-1251. (doi:10.1095/biolreprod.104.030726)

Jakimiuk AJ, Weitsman SR, Yen HW, Bogusiewicz M \& Magoffin DA 2002 Estrogen receptor $\alpha$ and $\beta$ expression in theca and granulosa cells from women with polycystic ovary syndrome. Journal of Clinical Endocrinology and Metabolism 87 5532-5538. (doi:10.1210/jc.2002020323)

Jo M, Komar CM \& Fortune JE 2002 Gonadotropin surge induces two separate increases in messenger RNA for progesterone receptor in bovine preovulatory follicles. Biology of Reproduction 67 1981-1988. (doi:10.1095/biolreprod.102.004366)

Kimura S, Matsumoto T, Matsuyama R, Shiina H, Sato T, Takeyama K \& Kato S 2007 Androgen receptor function in folliculogenesis and its clinical implication in premature ovarian failure. Trends in Endocrinology and Metabolism 18 183-189. (doi:10.1016/j.tem.2007. 04.002)

Manikkam M, Calder MD, Salfen BE, Youngquist RS, Keisler DH \& Garverick HA 2001 Concentrations of steroids and expression of messenger RNA for steroidogenic enzymes and gonadotropin receptors in bovine ovarian follicles of first and second waves and changes in second wave follicles after pulsatile LH infusion. Animal Reproduction Science 67 189-203. (doi:10.1016/S0378-4320(01)00120-8)

McInerney EM, Weis KE, Sun J, Mosselman S \& Katzenellenbogen BS 1998 Transcription activation by the human estrogen receptor subtype $\beta$ (ER $\beta$ ) studied with $\mathrm{ER} \beta$ and $\mathrm{ER} \alpha$ receptor chimeras. Endocrinology 139 4513-4522. (doi:10.1210/en.139.11.4513)

McKenna NJ, Lanz RB \& O'Malley BW 1999 Nuclear receptor coregulators: cellular and molecular biology. Endocrine Reviews 20 321-344. (doi:10.1210/er.20.3.321)

Mitev YA, Wolf SS, Almeida OF \& Patchev VK 2003 Developmental expression profiles and distinct regional estrogen responsiveness suggest a novel role for the steroid receptor coactivator NCOA1 as discriminative amplifier of estrogen signaling in the rat brain. FASEB Journal 17 518-519.

Monje L, Varayoud J, Muñoz-de-Toro M, Luque EH \& Ramos JG 2009 Neonatal exposure to bisphenol A alters estrogen-dependent mechanisms governing sexual behavior in the adult female rat. Reproductive Toxicology 28 435-442. (doi:10.1016/j.reprotox.2009. 06.012)

Monniaux D, di Clemente N, Touzè JL, Belville C \& Rico C 2008 Intrafollicular steroids and anti-Müllerian hormone during normal and cystic ovarian follicular development in the cow. Biology of Reproduction 79 387-396. (doi:10.1095/biolreprod.107.065847)

Montano MM, Ekena K, Delage-Mourroux R, Chang W, Martini P \& Katzenellenbogen BS 1999 An estrogen receptor-selective coregulator that potentiates the effectiveness of antiestrogens and represses the activity of estrogens. PNAS 96 6947-6952. (doi:10.1073/pnas.96.12. 6947)

Mosselman S, Polman J \& Dijkema R 1996 ERß: identification and characterization of a novel human estrogen receptor. FEBS Letters 392 49-53. (doi:10.1016/0014-5793(96)00782-X)
Mukherjee A, Amato P, Allred DC, DeMayo FJ \& Lydon JP 2007 Steroid receptor coactivator 2 is required for female fertility and mammary morphogenesis: insights from the mouse, relevance to the human. Nuclear Receptor Signaling 5 e011.

Murphy DD \& Segal M 1997 Morphological plasticity of dendritic spines in central neurons is mediated by activation of cAMP response element binding protein. PNAS 94 1482-1487. (doi:10.1073/pnas.94.4.1482)

Mussi P, Liao L, Park S, Ciana P, Maggi A, Katzenellenbogen BS, Xu J \& O'Malley BW 2006 Haploinsufficiency of the corepressor of estrogen receptor activity (REA) enhances estrogen receptor function in the mammary gland. PNAS 103 16716-16721. (doi:10.1073/pnas. 0607768103)

O'Brien ML, Park K, In Y \& Park-Sarge OK 1999 Characterization of estrogen receptor- $\beta$ (ER $\beta$ ) messenger ribonucleic acid and protein expression in rat granulosa cells. Endocrinology 140 4530-4541. (doi:10.1210/en.140.10.4530)

Ortega HH, Salvetti NR, Müller LA, Amable P, Lorente JA, Barbeito CG \& Gimeno EJ 2007a Characterization of cytoskeletal proteins in follicular structures of cows with cystic ovarian disease. Journal of Comparative Pathology 136 222-230. (doi:10.1016/j.jcpa.2007.02.001)

Ortega HH, Amable P, Salvetti NR, Dallard BE, Baravalle C, Barbeito C \& Gimeno EJ $2007 b$ Intraovarian localization of growth factors in induced cystic ovaries in rats. Anatomia, Histologia, Embryologia 36 94-102. (doi:10.1111/j.1439-0264.2006.00726.x)

Ortega HH, Palomar MM, Acosta JC, Salvetti NR, Dallard BE, Lorente JA, Barbeito CG \& Gimeno EJ 2008 Insulin-like growth factor I in ovarian follicles and follicular fluid from cows with spontaneous and induced cystic ovarian disease. Research in Veterinary Science 84 419-427. (doi:10.1016/j.rvsc.2007.05.010)

Ortega HH, Salvetti NR \& Padmanabhan V 2009 Developmental programming: prenatal androgen excess disrupt ovarian steroid receptor balance. Reproduction 137 865-877. (doi:10.1530/REP-08-0491)

Ortega HH, Rey F, Velazquez MM \& Padmanabhan V 2010 Developmental Programming: effect of prenatal steroid excess on intraovarian components of insulin signaling pathway and related proteins in sheep. Biology of Reproduction 82 1065-1075. (doi:10.1095/biolreprod.109. 082719)

Park SE, Xu J, Frolova A, Liao L, O’Malley BW \& Katzenellenbogen BS 2005 Genetic deletion of the repressor of estrogen receptor activity (REA) enhances the response to estrogen in target tissues in vivo. Molecular and Cellular Biology 25 1989-1999. (doi:10.1128/MCB.25.5.19891999.2005)

Peter AT 2004 An update on cystic ovarian degeneration in cattle. Reproduction in Domestic Animals 39 1-7. (doi:10.1046/j.0936-6768. 2003.00466.x)

Pettersson K, Grandien K, Kuiper GG \& Gustafsson JA 1997 Mouse estrogen receptor $\beta$ forms estrogen response element-binding heterodimers with estrogen receptor $\alpha$. Molecular Endocrinology 11 1486-1496. (doi:10.1210/me.11.10.1486)

Pettersson K, Delaunay F \& Gustafsson JA 2000 Estrogen receptor $\beta$ acts as a dominant regulator of estrogen signaling. Oncogene 19 4970-4978. (doi:10.1038/sj.onc.1203828)

Ranefall P, Wester K, Andersson AC, Busch C \& Bengtsson E 1998 Automatic quantification of immunohistochemically stained cell nuclei based on standard reference cells. Analytical Cellular Pathology 17 111-123.

Rey F, Rodríguez FM, Salvetti NR, Palomar MM, Barbeito CG, Alfaro NS \& Ortega HH 2010 Insulin-like growth-II and insulin-like growth factorbinding proteins in bovine cystic ovarian disease. Journal of Comparative Pathology 142 193-204. (doi:10.1016/j.jcpa.2009.11.002)

Rodríguez FM, Salvetti NR, Panzani CG, Barbeito CG, Ortega HH \& Rey F 2011 Influence of insulin-like growth factor-binding proteins-2 and - 3 in the pathogenesis of cystic ovarian disease in cattle. Animal Reproduction Science 128 1-10. (doi:10.1016/j.anireprosci.2011.08.007)

Rosenfeld CS, Wagner JS, Roberts RM \& Lubahn DB 2001 Intraovarian actions of oestrogen. Reproduction 122 215-226. (doi:10.1530/rep.0. 1220215)

Salvetti NR Caracterización de la expresión de receptores hormonales y del balance proliferación/apoptosis en la Enfermedad Quística Ovárica Bovina. PhD Thesis, p 141, 2010. Universidad Nacional del Litoral, Santa Fe, Argentina. 
Salvetti NR, Gimeno EJ, Lorente JA \& Ortega HH 2004 Expression of cytoskeletal proteins in the follicular wall of induced ovarian cysts. Cells, Tissues, Organs 178 117-125. (doi:10.1159/000081721)

Salvetti NR, Muller LA, Acosta JC, Gimeno JE \& Ortega HH 2007 Estrogen receptors $\alpha$ and $\beta$ and progesterone receptors in ovarian follicles of cows with cystic ovarian disease. Veterinary Pathology 44 373-378. (doi:10.1354/vp.44-3-373)

Salvetti NR, Panzani CG, Gimeno EJ, Neme LG, Alfaro NS \& Ortega HH 2009a An imbalance between apoptosis and proliferation contributes to follicular persistence in polycystic ovaries in rats. Reproductive Biology and Endocrinology 7 68. (doi:10.1186/1477-7827-7-68)

Salvetti NR, Baravalle C, Mira GA, Gimeno EJ, Dallard BE, Rey F \& Ortega HH 2009b Heat shock protein 70 and sex steroid receptors in the follicular structures of induced ovarian cysts. Reproduction in Domestic Animals 44 805-814. (doi:10.1111/j.1439-0531.2008.01086.x)

Salvetti NR, Stangaferro ML, Palomar MM, Alfaro NS, Rey F, Gimeno EJ \& Ortega HH 2010 Cell proliferation and survival mechanisms underlying the abnormal persistence of follicular cysts in bovines with cystic ovarian disease induced by ACTH. Animal Reproduction Science 122 98-110. (doi:10.1016/j.anireprosci.2010.08.003)

Sarvilinna N, Eronen H, Miettinen S, Vienonen A \& Ylikomi T 2006 Steroid hormone receptors and coregulators in endocrine-resistant and estrogenindependent breast cancer cells. International Journal of Cancer 118 832-840. (doi:10.1002/ijc.21431)

Schams D \& Berisha B 2002 Steroids as local regulators of ovarian activity in domestic animals. Domestic Animal Endocrinology 23 53-65. (doi:10.1016/S0739-7240(02)00145-5)

Schams D, Kohlenberg S, Amselgruber W, Berisha B, Pfaffl MW \& Sinowatz F 2003 Expression and localisation of oestrogen and progesterone receptors in the bovine mammary gland during development, function and involution. Journal of Endocrinology 177 305-317. (doi:10.1677/joe.0.1770305)

Sette C, Messina V \& Paronetto MP 2010 Sam68: a new STAR in the male review fertility firmament. Journal of Andrology 31 66-74. (doi:10.2164/ jandrol.109.008136)

Shushan A, Peretz T, Uziely B, Lewin A \& Mor-Yosef S 1996 Ovarian cysts in premenopausal and postmenopausal tamoxifen-treated women with breast cancer. American Journal of Obstetrics and Gynecology 174 141-144. (doi:10.1016/S0002-9378(96)70386-1)

Silvia WJ, Hatler TB, Nugent AM \& Laranja da Fonseca LF 2002 Ovarian follicular cysts in dairy cows: an abnormality in folliculogenesis. Domestic Animal Endocrinology 23 167-177. (doi:10.1016/S07397240(02)00154-6)

Sirois J \& Fortune JE 1988 Ovarian follicular dynamics during estrous cycle in heifers monitored by real-time ultrasonography. Biology of Reproduction 39 308-317. (doi:10.1095/biolreprod39.2.308)
Tanner MM, Grenman S, Koul A, Johannsson O, Meltzer P, Pejovic T, Borg A \& Tsola JJ 2000 Frequent amplification of chromosomal region 20q12-q13 in ovarian cancer. Clinical Cancer Research 6 1833-1839.

Tetsuka M \& Hillier SG 1997 Differential regulation of aromatase and androgen receptor in granulosa cells. Journal of Steroid Biochemistry and Molecular Biology 61 233-239. (doi:10.1016/S0960-0760(97)80017-9)

Van den Broeck W, Coryn M, Simoens P \& Lauwers H 2002a Cell-specific distribution of oestrogen receptor- $\alpha$ in the bovine ovary. Reproduction in Domestic Animals 37 291-293. (doi:10.1046/j.1439-0531.2002. 00352.x)

Van den Broeck W, D'Haeseleer M, Coryn M \& Simoens P $2002 b$ Cell-specific distribution of progesterone receptors in the bovine ovary. Reproduction in Domestic Animals 37 314-320. (doi:10.1046/j.14390531.2002.00366.x)

Vanholder T, Opsomer G \& De Kruif A 2006 Aetiology and pathogenesis of cystic ovarian follicles in dairy cattle: a review. Reproduction, Nutrition, Development 46 105-119. (doi:10.1051/rnd:2006003)

Varayoud J, Monje L, Bernhardt T, Muñoz-de-Toro M, Luque EH \& Ramos JG 2008 Endosulfan modulates estrogen-dependent genes like a non-uterotrophic dose of $17 \beta$-estradiol. Reproductive Toxicology 26 138-145. (doi:10.1016/j.reprotox.2008.08.004)

Velázquez MML, Alfaro NS, Dupuy CRF, Salvetti NR, Rey F \& Ortega HH 2010 Heat shock protein patterns in the bovine ovary and relation with cystic ovarian disease. Animal Reproduction Science 118 201-209. (doi:10.1016/j.anireprosci.2009.08.010)

Velázquez MML, Alfaro NS, Salvetti NR, Stangaferro ML, Rey F, Panzani CG \& Ortega HH 2011 Levels of heat shock protein transcripts in normal follicles and ovarian follicular cysts. Reproductive Biology $\mathbf{1 1}$ 276-283.

Vendola KA, Zhou J, Adesanya OO, Weil SJ \& Bondy CA 1998 Androgens stimulate early stages of follicular growth in the primate ovary. Journal of Clinical Investigation 15 2622-2629. (doi:10.1172/JCI2081)

Walters KA, Allan CM \& Handelsman DJ 2008 Androgen actions and the ovary. Biology of Reproduction 78 380-389. (doi:10.1095/biolreprod. 107.064089)

Zhang H, Liao L, Kuang SQ \& Xu J 2003 Spatial distribution of the messenger ribonucleic acid and protein of the nuclear receptor coactivator, amplified in breast cancer-3, in mice. Endocrinology 144 1435-1443. (doi:10.1210/en.2002-0018)

Received 22 May 2012

First decision 8 June 2012

Revised manuscript received 4 October 2012

Accepted 15 October 2012 